\title{
Clinical and pathobiological heterogeneity of asthma-Mechanisms of severe and glucocorticoid-resistant asthma
}

\author{
Yasuhiro Matsumura \\ Department of Internal Medicine, Akishima Hospital, Tokyo, Japan; \\ y-matsumura@aki-hp.jp
}

Received 14 December 2012; revised 15 January 2013; accepted 23 January 2013

\begin{abstract}
It is increasingly recognized that asthma represents a syndrome, and there is clinical and pathobiological heterogeneity. Many genes are reported to be associated with asthma, and may be involved in the disease heterogeneity. Diverse cells, such as T helper 1 (Th1)-cells, Th2cells, Th17-cells, airway epithelial cells, and innate and adaptive immunity associated cells, contribute to the pathobiology of asthma independently of each other or they can also coexist and interact. Although, generally, Th2 immunity is important in most asthma endotypes, nonTh2-driven inflammation tends to be difficult to manage. Recently, increased attention has been focused on severe asthma and glucocorticoid (GC)-resistant (GC-R) asthma, in which diverse inflammatory processes may be involved. Treatment approaches should take into account pathological differences.
\end{abstract}

Keywords: Asthma Phenotype; Genome-Wide Association Study (GWAS); Glucocorticoid (GC)-Resistant (GC-R) Asthma; Severe Asthma

\section{INTRODUCTION}

Asthma is a chronic inflammatory disease characterized by episodic and reversible airway obstruction and bronchial hyper-responsiveness. Allergic involvement, age at onset, exacerbating factors, and response to treatment differ in each individual. In common with other complex diseases, asthma is a heterogeneous and genetically complex disease, and in some patients factors can coexist [1-3]. The recent discovery of new asthma-associated genes and new mechanisms of immunity and inflammation reinforces the concept of clinical heterogeneity of asthma. Despite conventional therapy, including bronchodilators, leukotriene modifiers, and GCs, some patients do not respond satisfactorily to therapy, and attention is now focused on severe and GC-R asthma. Accurate definition of asthmatic phenotypes may facilitate clinical investigation of the pathogenesis and be useful for treatment of asthma. This review summarizes the clinical and pathobiological phenotypes of asthma, and discusses the mechanisms of GC resistance.

\section{GENETIC BACKGROUND OF ASTHMA}

More than 100 genes have already been implicated. One mechanism alone cannot explain the pathogenesis of asthma. Asthma susceptibility genes fall into four main groups: genes associated with innate immunity and immunoregulation; genes associated with Th2-cell differentiation and effector functions; genes associated with epithelial biology and mucosal immunity; and genes associated with lung function, airway remodelling and disease severity [4]. Asthmatics are not always equally influenced by those genes, and the involvement of each gene may differ among individuals, suggesting heterogeneity.

Recently, two meta-analyses of asthma genome-wide association studies (GWAS) have been completed, one by the GABRIEL Consortium, which discovered that the IL18R1, IL33, SMAD3, ORMDL3, HLA-DQ and IL2RB loci were all significantly associated with asthma [5], and one by the EVE Consortium [6]. These investigations especially have highlighted the importance of variation of genes in airway epithelial cells for various immune and inflammatory processes in asthma [7].

\section{CELLULAR INFLAMMATORY PHENOTYPES}

Concepts of asthma pathogenesis in inflammation continue to evolve. There has been a predominant view that a Th2-predominant phenotype and Th2 cytokines such as IL-4, IL-5, and IL13 predispose to the development of asthma. Th1 cells previously had been regarded 
to inhibit bronchial asthma by virtue of IFN- $\gamma$, but recently, bronchial asthma has been considered a complicated disease induced by the functions of Th1 and Th2 cells. The adoptive transfer of antigen-specific Th1 cells into ovalbumin-challenged mice led to the development of airway hyper-responsiveness and airway inflammation that was independent of IL-13 and IL-4 [8]. In addition, Th1 cells become pathological super Th1 cells when stimulated with Ag and IL-18, through the production of IFN- $\gamma$ and IL-13, which in combination induces AHR, peribronchial inflammation, and lung fibrosis in a mouse model of asthma [9]. Th17 cells have come to attention and been added as a third distinct T-helper cell subset, which produces IL-17A, IL-17F, and IL-22. On allergen sensitization, Th17 cells home to the lung and enhance both Th2 cell-mediated eosinophilic airway inflammation and neutrophilic airway inflammation in mouse models of asthma [10,11]. Th17 cells, which mediate Th2independent neutrophilic inflammation, have also been shown in IL-17F transgenic and knockout mice [12]. Although the role of Th17 cytokines in neutrophil recruitment is still unclear, IL-17 has been suggested as a mediator of neutrophil variant and severe neutrophilic asthma endotypes [13].

Recently, investigation of asthma pathogenesis has focused on innate immunity and epithelial function. Activation of innate immune responses also leads to production of Th2-type cytokines or skewing of responses toward the Th2 pattern. Epithelial cells are involved in the initiation of allergic response in the airway by releasing thymic stromal lymphopoietin (TSLP), IL-33, and IL-25 in response to allergens. TSLP mediates migration of dendric cells (DC), resulting in presentation of antigens, differentiation of T-helper cells, and production of the Th2 cytokines IL-4, IL-5, and IL13.

\section{CLINICAL PHENOTYPES OF ASTHMA}

To identify the characteristic phenotypes of asthma, factor analysis from questionnaire, clinical, and laboratory data, including baseline pulmonary function and allergen skin prick test results, has been performed in physician-diagnosed asthma and symptomatic siblings in nuclear families and has demonstrated its heterogeneity [14]. Trials to discriminate asthma phenotypes by cluster analysis $[15,16]$ have been reported. The National Heart Lung and Blood Institute-sponsored Severe Asthma Research Program (SARP) identified and characterized novel asthma phenotypes using unsupervised hierarchical cluster analysis. Five groups were identified. Subjects in Cluster 1 have early onset atopic asthma with normal lung function treated with two or fewer controller medications and minimal health care utilization. Cluster 2 consists of subjects with early-onset atopic asthma and preserved lung function but increased medication re- quirements and health care utilization. Cluster 3 is a unique group of mostly older obese women with lateonset nonatopic asthma, moderate reductions in $\mathrm{FEV}_{1}$, and frequent oral corticosteroid use to manage exacerbations. Subjects in Clusters 4 and 5 have severe airflow obstruction with bronchodilator responsiveness but differ in to their ability to attain normal lung function, age of asthma onset, atopic status, and use of oral corticosteroids [17]. An important contribution of the SARP study, a cluster analysis, was the creation of a decision tree from variables readily available in the clinic. Cytokine profiles in bronchoalveolar lavage (BAL) samples [18] have also been studied.

\section{SEVERE ASTHMA PHENOTYPE}

Asthma heterogeneity is recognized in severe asthma, where patients have diverse symptom profiles and altered responses to medication. Collaborative investigations of difficult asthma by the European Network for Understanding Mechanisms of Severe asthma [19] and the Severe Asthma Research Program in the United States [20] have been carried out.

Genetic polymorphisms are associated with asthma severity. TGF $\beta 1$ causes tissue fibrosis and extracellular tissue deposition of matrix components and is believed to be involved in airway remodeling. It has been reported that the $-509 \mathrm{~T}$ allele in the $-509 \mathrm{C}>\mathrm{T}$ polymorphism of the TGF $\beta 1$ gene is correlated with severe asthma [21]. It has been demonstrated that epidermal growth factor receptor (EGFR) plays an important role in tissue remodeling of the airways in asthma. Many patients with severe asthma have a small number of CA repeats in intron 1 of the EGFR gene [22]. The IL4* ${ }^{*}-589 \mathrm{~T}$ allele is a risk factor for life-threatening asthma and the IL4RA ${ }^{*} 576 \mathrm{R}$ allele is a risk factor for poor lung function in asthmatic subjects [23].

Eosinophilic inflammation is a Th2-driven trait that is important in some asthma endotypes. Endobronchial biopsy [24] and induced-sputum analysis [25] in severe and persistent asthma demonstrated involvement of neutrophil influx and activation, which may be mediated by IL-8 secretion. Th1 cells play a critical role in pulmonary neutrophilia, coupled with the production of CXC chemokines [26]. High mobility group box 1 (HMGB-1), a ligand of the receptor for advanced glycation end products (RAGE), is a mediator of neutrophilic airway inflammation in asthma, and imbalance between HMGB-1 and esRAGE is related to the severity of asthma [27]. Neutrophilia has been noted during acute asthma exacerbations [28], and has been reported to be associated with infection, exposure to pollutants, smoking, and obesity [29]. In general, the condition of patients with neutronphilic asthma tends to be severe, and this comprises one endotype of asthma. 
Mast cells (MCs) contribute to the pathophysiology of asthma, and airway smooth muscle (ASM) infiltration is important in determining the asthma endotype. Mast cells infiltrate the airway mucous glands and show a positive correlation with the degree of mucus obstructing the airway lumen, suggesting their role in regulation of mucous gland secretion. Comparison of subjects with asthma and normal subjects in the Severe Asthma Research Program revealed that severe asthma is associated with a predominance of MCs in the airway submucosa and epithelium [30].

Eosinophilic inflammation and airway remodelling occur in children with early respiratory symptoms before a clear clinical diagnosis of bronchial asthma can be made [31]. Remodeling has been postulated to be the result of persistent inflammation in the bronchial wall, associated with the production of inflammatory cytokines and growth factors. Reportedly, severe asthma is different from non-severe asthma by increased airway wall remodelling rather than by differences in inflamematory cell numbers [32].

\section{GC-R ASTHMA}

The response to GCs in asthma is very heterogeneous [33], and may have a genetic basis. Variations in the stress-induced-phosphoprotein-1 (STIP-1) gene, which encodes components of the GR complex [34], and the glucocorticoid-induced transcript 1 (GLCCI1) gene might be involved in GC response [35].

Mostly, GC sensitivity is modified by inflammatory response. Generally, non-Th2-dependent, non-eosinophilic asthma is associated with a poor response to GCs [36]. Th1-dependent inflammation [37,38], neutrophilic inflammation [39], and Th17-driven inflammation are recognized to be associated with GC-R asthma [40-42]. Factors related to innate immunity may result in GC resistance [37].

The phosphorylation status of GR plays a critical role in controlling GR properties such as nuclear translocation. The status is largely influenced by kinase signaling and phosphatases [43-45]. An increase in the inactive $\mathrm{GR} \beta$ isoform alters GC response in GC resistance [46] by controlling HDAC2 expression [47]. However, the roles of $\mathrm{GR} \beta$ in modulating $\mathrm{GC}$ sensitivity have been highly debated [48].

Most of the anti-inflammatory actions of GCs can be accounted for by inhibition of transcription factors, mainly activator protein-1 (AP-1) and nuclear factorkappa B (NF- $\kappa \mathrm{B})$, which regulate inflammatory gene expression. The interaction is mutually antagonistic, suggesting its contribution to GC-R asthma. Protein-protein interactions between activated GR and other transcription factors may also play an important role in GC-R asthma. Whereas interferon regulatory factor-1 (IRF-1)
[49] inhibits GR action, CCAAT enhancer-binding protein (C/EBP) [50], activating transcription factor 3 (ATF3) [51], and nuclear factor (erythroid-derived 2)-related 2 (Nrf2) [52] promote GR function.

p38 mitogen-activated protein kinase (MAPK) acts on a variety of substrates including transcription factors, such as NF- $\kappa$ B and AP-1. MAPK-mediated inhibition of GR function appears to be key to GC resistance [53-55]. Phosphoinositide 3-kinase (PI3K) plays an integral role in the immune system, in both MC and eosinophil function, and may be crucial in mediating GC insensitivity after oxidative stress via decreased activity of HDAC2 [56].

Preventable risk factors that modify GC-responsiveness, such as vitamin D deficiency [57], smoking [58,59], and obesity [60] are recognized.

\section{FUTURE PROSPECTS}

GWASs are revealing new asthma susceptibity genes that are expressed in the airway epithelium and innate immunity pathways. Advances in understanding of the sentinel role played by airway epithelium function and innate immunity in asthma promote the concept of nonTh-2-driven pathways underlying airway inflammation. The association of asthma-related genes and different cellular phenotypes with clinical phenotypes and response to therapy is a big issue, which should be analyzed. Despite widespread use of inhaled GCs, there are still patients with severe asthma phenotypes. Although dissociated GCs may provide greater steroid potency with fewer adverse-effects, GC therapy does not always cover all asthma phenotypes. Immunosuppressants, such as methotrexate and cyclosporine A, and biological molecules, such as omalizumab, mepolizumab and etanercept, may have useful steroid-sparing effects in severe asthma. Among severe asthma phenotypes, GC-R asthma is one particular phenotype that is expected to be treated by new therapeutic strategies, such as p38 MAPK inhibitors and $\mathrm{P} I 3 \mathrm{~K} \delta$ inhibitors.

\section{CONCLUSION}

Genetic background and various inflammatory pathways contribute to asthma phenotype. There is great hope that clinical clustering analysis will be useful to predict disease severity and response to therapy. Recognition of the phenotype of asthmatic patients may offer a better understanding of the pathobiology of the disease and lead to personalized therapy.

\section{REFERENCES}

[1] Anderson GP. (2008) Endotyping asthma: New insights into key pathogenic mechanisms in a complex, heteroge- 
neous disease. Lancet, 372, 1107-1119. doi:10.1016/S0140-6736(08)61452-X

[2] Kim, H.Y., DeKruyff, R.H. and Umetsu, D.T. (2010) The many paths to asthma: Phenotype shaped by innate and adaptive immunity. Nature Immunology, 11, 577-584. Epub 18 June 2010. doi:10.1038/ni.1892

[3] Bhakta, N.R. and Woodruff, P.G. (2011) Human asthma phenotypes: From the clinic, to cytokines, and back again. Immunological Reviews, 242, 220-232. doi:10.1111/j.1600-065X.2011.01032.x

[4] Vercelli D. (2008) Discovering susceptibility genes for asthma and allergy. Nature reviews. Immunology, 8, 169182. doi: $10.1038 /$ nri2257

[5] Moffatt, M.F., Gut, I.G., Demenais, F., Strachan, D.P., Bouzigon, E., Heath, S., von Mutius, E., Farrall, M., Lathrop, M. and Cookson, W.O.; GABRIEL Consortium (2010) A large-scale, consortium-based genomewide association study of asthma. The New England Journal of Medicine, 363, 1211-1221.

doi:10.1056/NEJMoa0906312

[6] Torgerson, D.G., Ampleford, E.J., Chiu, G.Y., Gauderman, W.J., Gignoux, C.R., Graves, P.E., Himes, B.E., Levin, A.M., Mathias, R.A., Hancock, D.B., Baurley, J.W., Eng, C., Stern, D.A., Celedón, J.C., Rafaels, N., Capurso, D., Conti, D.V., Roth, L.A., Soto-Quiros, M., Togias, A., Li, X., Myers, R.A., Romieu, I., Van Den Berg, D.J., Hu, D., Hansel, N.N., Hernandez, R.D., Israel, E., Salam, M.T., Galanter, J., Avila, P.C., Avila, L., Rodriquez-Santana, J.R., Chapela, R., Rodriguez-Cintron, W., Diette, G.B., Adkinson, N.F., Abel, R.A., Ross ,K.D., Shi, M., Faruque, M.U., Dunston, G.M., Watson, H.R., Mantese, V.J., Ezurum. S.C., Liang, L., Ruczinski, I., Ford, J.G., Huntsman, S., Chung, K.F., Vora, H., Li, X., Calhoun, W.J., Castro, M., Sienra-Monge, J.J., del Rio-Navarro, B., Deichmann, K.A., Heinzmann, A., Wenzel, S.E., Busse, W.W., Gern, J.E., Lemanske Jr., R.F., Beaty, T.H., Bleecker, E.R., Raby, B.A., Meyers, D.A., London, S.J.; Mexico City Childhood Asthma Study (MCAAS), Gilliland, F.D.; Children's Health Study (CHS) And HARBORS Study, Burchard, E.G.; Genetics of Asthma in Latino Americans (GALA) Study, Study of Genes-Environment and Admixture in Latino Americans (GALA2) and Study of African Americans, Asthma, Genes \& Environments (SAGE), Martinez, F.D.; Childhood Asthma Research and Education (CARE) Network, Weiss, S.T.; Childhood Asthma Management Program (CAMP), Williams, L.K.; Study of Asthma Phenotypes and Phar-macogenomic Interactions by Race-Ethnicity (SAP-PHIRE), Barnes, K.C.; Genetic Research on Asthma in African Diaspora (GRAAD) Study, Ober, C. and Nicolae, D.L. (2011) Meta-analysis of genome-wide association studies of asthma in ethnically diverse North American populations. Nature Genetics, 43, 887-892. doi:10.1038/ng.888

[7] Ober, C. and Yao, T.C. (2011) The genetics of asthma and allergic disease: A 21 st century perspective. Immunological Reviews, 242, 10-30. doi:10.1111/j.1600-065X.2011.01029.X

[8] Cui, J., Pazdziorko, S., Miyashiro, J.S., Thakker, P., Pelker, J.W., Declercq, C., Jiao, A., Gunn, J., Mason, L., Leonard, J.P., Williams, C.M. and Marusic, S. (2005)
TH1-mediated airway hyperresponsiveness independent of neutrophilic inflammation. The Journal of Allergy and Clinical Immunology, 115, 309-315. doi:10.1016/j.jaci.2004.10.046

[9] Hayashi, N., Yoshimoto, T., Izuhara, K., Matsui, K., Tanaka, T. and Nakanishi, K. (2007) T helper 1 cells stimulated with ovalbumin and IL-18 induce airway hyperresponsiveness and lung fibrosis by IFN-gamma and IL-13 production. Proceedings of the National Academy of Sciences of the United States of America, 2104, 1476514770. Epub August 312007. doi:10.1073/pnas.0706378104

[10] Wakashin, H., Hirose, K., Maezawa, Y., Kagami, S., Suto, A., Watanabe, N., Saito, Y., Hatano, M., Tokuhisa, T., Iwakura, Y., Puccetti, P., Iwamoto, I. and Nakajima, H. (2008) IL-23 and Th17 cells enhance Th2-cell-mediated eosinophilic airway inflammation in mice. American Journal of Respiratory and Critical Care Medicine, 178, 1023-1032. Epub 11 September 2008. doi:10.1164/rcem.200801-0860C

[11] Wilson, R.H., Whitehead, G.S., Nakano, H., Free, M.E., Kolls, J.K. and Cook, D.N. (2009) Allergic sensitization through the airway primes Th17-dependent neutrophilia and airway hyperresponsiveness. American Journal of Respiratory and Critical Care Medicine, 180, 720-730. Epub 6 August 2009. doi:10.1164/rccm.200904-0573OC

[12] Yang, X.O., Chang, S.H., Park, H., Nurieva, R., Shah, B., Acero, L., Wang, Y.H., Schluns, K.S., Broaddus, R.R., Zhu, Z. and Dong, C. (2008) Regulation of inflammatory responses by IL-17F. The Journal of Experimental Medicine, 205, 1063-1075. Epub 14 April 2008. doi: $10.1084 /$ jem. 20071978

[13] Pène, J., Chevalier, S., Preisser, L., Vénéreau, E., Guilleux, M.H., Ghannam, S., Molès, J.P., Danger, Y., Ravon, E., Lesaux, S., Yssel, H. and Gascan, H. (2008) Chronically inflamed human tissues are infiltrated by highly differentiated Th17 lymphocytes. The Journal of Immunology: Official Journal of the American Association of Immunologists, 180, 7423-7430.

[14] Pillai, S.G., Tang, Y., van den Oord, E., Klotsman, M., Barnes, K., Carlsen. K., Gerritsen, J., Lenney, W., Silverman, M., Sly, P., Sundy, J., Tsanakas, J., von Berg, A., Whyte, M., Ortega, H.G., Anderson, W.H. and Helms, P.J. (2008) Factor analysis in the Genetics of Asthma International Network family study identifies five major quantitative asthma phenotypes. Clinical and Experimental Allergy: Journal of the British Society for Allergy and Clinical Immunology, 38, 421-429. Epub 2 January 2008. doi:10.1111/j.1365-2222.2007.02918.x

[15] Haldar, P., Pavord, I.D., Shaw, D.E., Berry, M.A., Thomas, M., Brightling, C.E., Wardlaw, A.J. and Green, R.H. (2008) Cluster analysis and clinical asthma phenotypes. American Journal of Respiratory and Critical Care Medicine, 178, 218-224. Epub 14 May 2008. doi:10.1164/rccm.200711-17540C

[16] Weatherall, M., Travers, J., Shirtcliffe, P.M., Marsh, S.E., Williams, M.V., Nowitz, M.R., Aldington, S. and Beasley, R. (2009) Distinct clinical phenotypes of airways disease defined by cluster analysis. The European Respiratory Journal: Official Journal of the European Society for 
Clinical Respiratory Physiology, 34, 812-818. Epub 8 April 2009. doi:10.1183/09031936.00174408

[17] Moore, W.C., Meyers, D.A., Wenzel, S.E., Teague, W.G., Li, H., Li, X., D’Agostino Jr., R., Castro, M., CurranEverett, D., Fitzpatrick, A.M., Gaston, B., Jarjour, N.N., Sorkness, R., Calhoun, W.J., Chung, K.F., Comhair, S.A., Dweik, R.A., Israel, E., Peters, S.P., Busse, W.W., Erzurum, S.C. and Bleecker, E.R.; National Heart, Lung, and Blood Institute's Severe Asthma Research Program (2010) Identification of asthma phenotypes using cluster analysis in the severe asthma research program. American Journal of Respiratory and Critical Care Medicine, 181, 315-323. Epub 5 November 2009. doi:10.1164/rccm.200906-08960C

[18] Brasier, A.R., Victor, S., Boetticher, G., Ju, H., Lee, C., Bleecker, E.R., Castro, M., Busse, W.W. and Calhoun, W.J. (2008) Molecular phenotyping of severe asthma using pattern recognition of bronchoalveolar lavage-derived cytokines. The Journal of Allergy and Clinical Immunology, 121, 30-37, e6. doi:10.1016/j.jaci.2007.10.015

[19] Holgate, S.T. (2003) The ENFUMOSA cross-sectional European multicentre study of the clinical phenotype of chronic severe asthma. European network for understanding mechanisms of severe asthma. The European Respiratory Journal: Official Journal of the European Society for Clinical Respiratory Physiology, 22, 470-477.

[20] Moore, W.C., Bleecker, E.R., Curran-Everett, D., Erzurum, S.C., Ameredes, B.T., Bacharier, L., Calhoun, W.J., Castro, M., Chung, K.F., Clark, M.P., Dweik, R.A., Fitzpatrick, A.M., Gaston, B., Hew, M., Hussain, I., Jarjour, N.N., Israel, E., Levy, B.D., Murphy, J.R., Peters, S.P., Teague, W.G., Meyers, D.A., Busse, W.W. and Wenzel, S.E.; National Heart, Lung, Blood Institute's Severe Asthma Research Program (2007) Characterization of the severe asthma phenotype by the national heart, lung, and blood institute's severe asthma research program. The Journal of Allergy and Clinical Immunology, 119, 405413. doi:10.1016/j.jaci.2006.11.639

[21] Pulleyn, L.J., Newton, R., Adcock, I.M. and Barnes, P.J. (2001) TGFbetal allele association with asthma severity. Human Genetics, 109, 623-627. Epub27 October 2001.

[22] Wang, X., Saito, J., Ishida, T. and Munakata, M. (2006) Polymorphism of egfr Intron1 is associated with susceptibility and severity of asthma. The Journal of Asthma: Official Journal of the Association for the Care of Asthma, 43, 711-715. doi:10.1007/s00439-001-0617-y

[23] Sandford, A.J., Chagani, T., Zhu, S., Weir, T.D., Bai, T.R., Spinelli, J.J., Fitzgerald, J.M., Behbehani, N.A., Tan, W.C. and Paré, P.D. (2000) Polymorphisms in the IL4, IL4RA, and FCERIB genes and asthma severity. The Journal of Allergy and Clinical Immunology, 106, 135-140. doi:10.1067/mai.2000.107926

[24] Wenzel, S.E., Schwartz, L.B., Langmack, E.L., Halliday, J.L., Trudeau, J.B., Gibbs, R.L. and Chu, H.W. (1999) Evidence that severe asthma can be divided pathologically into two inflammatory subtypes with distinct physiologic and clinical characteristics. American Journal of Respiratory and Critical Care Medicine, 160, 1001-1008.

[25] Gibson, P.G., Simpson, J.L. and Saltos, N. (2001) Heterogeneity of airway inflammation in persistent asthma:
Evidence of neutrophilic inflammation and increased sputum interleukin-8. Chest, 119, 1329-1336. doi:10.1378/chest.119.5.1329

[26] Takaoka, A., Tanaka, Y., Tsuji, T., Jinushi, T., Hoshino, A., Asakura, Y., Mita, Y., Watanabe, K., Nakaike, S., Togashi, Y., Koda, T., Matsushima, K. and Nishimura, T. (2001) A critical role for mouse CXC chemokine(s) in pulmonary neutrophilia during Th type 1-dependent airway inflammation. The Journal of Immunology: Official Journal of the American Association of Immunologists, 167, 23492353.

[27] Watanabe, T., Asai, K., Fujimoto, H., Tanaka, H., Kanazawa, H. and Hirata, K. (2011) Increased levels of HMGB1 and endogenous secretory RAGE in induced sputum from asthmatic patients. Respiratory Medicine, 105, 519525. Epub 30 October 2010. doi:10.1016/j.rmed.2010.10.016

[28] Fahy, J.V., Kim, K.W., Liu, J. and Boushey, H.A. (1995) Prominent neutrophilic inflammation in sputum from subjects with asthma exacerbation. The Journal of Allergy and Clinical Immunology, 95, 843-852. doi:10.1016/S0091-6749(95)70128-1

[29] Haldar, P. and Pavord, I.D. (2007) Noneosinophilic asthma: A distinct clinical and pathologic phenotype. The Journal of Allergy and Clinical Immunology, 119, 1043 1052; Quiz 1053-1054. doi:10.1016/j.jaci.2007.02.042

[30] Balzar, S., Fajt, M.L., Comhair, S.A., Erzurum, S.C., Bleecker, E., Busse, W.W., Castro, M., Gaston, B., Israel, E., Schwartz, L.B., Curran-Everett, D., Moore, C.G. and Wenzel, S.E. (2011) Mast cell phenotype, location, and activation in severe asthma. Data from the Severe Asthma Research Program. American Journal of Respiratory and Critical Care Medicine, 183, 299-309. Epub 2 September 2010. doi:10.1164/rccm.201002-0295OC

[31] Pohunek, P., Warner, J.O., Turzíková, J., Kudrmann, J. and Roche, W.R. (2005) Markers of eosinophilic inflammation and tissue re-modelling in children before clinically diagnosed bronchial asthma. Pediatric Allergy and Immunology: Official Publication of the European Society of Pediatric Allergy and Immunology, 16, 43-51.

[32] Macedo, P., Hew, M., Torrego, A., Jouneau, S., Oates, T., Durham, A. and Chung, K.F. (2009) Inflammatory biomarkers in airways of patients with severe asthma compared with non-severe asthma. Clinical and Experimental Allergy: Journal of the British Society for Allergy and Clinical Immunology, 39, 1668-1676. Epub 20 July 2009. doi:10.1111/j.1365-2222.2009.03319.x

[33] Szefler, S.J., Martin, R.J., King, T.S., Boushey, H.A., Cherniack, R.M., Chinchilli, V.M., Craig, T.J., Dolovich, M., Drazen, J.M., Fagan, J.K., Fahy, J.V., Fish, J.E., Ford, J.G., Israel, E., Kiley, J., Kraft, M., Lazarus, S.C., Lemanske Jr., R.F., Mauger, E., Peters, S.P. and Sorkness, C.A.; Asthma Clinical Research Network of the National Heart Lung, and Blood Institute (2002) Significant variability in response to inhaled corticosteroids for persistent asthma. The Journal of Allergy and Clinical Immunology, 109, 410-418. doi:10.1067/mai.2002.122635

[34] Hawkins, G.A., Lazarus, R., Smith, R.S., Tantisira, K.G., Meyers, D.A., Peters, S.P., Weiss, S.T. and Bleecker, E.R. 
(2009) The glucocorticoid receptor heterocomplex gene STIP1 is associated with improved lung function in asthmatic subjects treated with inhaled corticosteroids. The Journal of Allergy and Clinical Immunology, 123, 1376-1383, e7. Epub 28 February 2009.

doi:10.1016/j.jaci.2009.01.049

[35] Tantisira, K.G., Lasky-Su, J., Harada, M., Murphy, A., Litonjua, A.A., Himes, B.E., Lange, C., Lazarus, R., Sylvia, J., Klanderman, B., Duan, Q.L., Qiu, W., Hirota, T., Martinez, F.D., Mauger, D., Sorkness, C., Szefler, S., Lazarus, S.C., Lemanske Jr., R.F., Peters, S.P., Lima, J.J., Nakamura, Y., Tamari, M. and Weiss, S.T. (2001) Genomewide association between GLCCI1 and response to glucocorticoid therapy in asthma. The New England Journal of Medicine, 365, 1173-1183. Epub 26 September 2011. doi:10.1056/NEJMoa0911353

[36] Pavord, I.D., Brightling, C.E., Woltmann, G. and Wardlaw, A.J. (1999) Non-eosinophilic corticosteroid unresponsive asthma. Lancet, 26353, 2213-2214. doi:10.1016/S0140-6736(99)01813-9

[37] Yang, M., Kumar, R.K. and Foster, P.S. (2009) Pathogenesis of steroid-resistant airway hyperresponsiveness: Interaction between IFN-gamma and TLR4/MyD88 pathways. The Journal of Immunology: Official Journal of the American Association of Immunologists, 182, 5107-5115. doi:10.4049/jimmunol.0803468

[38] Heaton, T., Rowe, J., Turner, S., Aalberse, R.C., de Klerk, N., Suriyaarachchi, D., Serralha, M., Holt, B.J., Hollams, E., Yerkovich, S., Holt, K., Sly, P.D., Goldblatt, J., Le Souef, P. and Holt, P.G. (2005) An immunoepidemiological approach to asthma: Identification of in-vitro T-cell response patterns associated with different wheezing phenotypes in children. Lancet, 365, 142-149. doi:10.1016/S0140-6736(05)17704-6

[39] Ito, K., Herbert, C., Siegle, J.S., Vuppusetty, C., Hansbro, N., Thomas, P.S., Foster, P.S., Barnes, P.J. and Kumar, R.K. (2008) Steroid-resistant neutrophilic inflammation in a mouse model of an acute exacerbation of asthma. American Journal of Respiratory Cell and Molecular Biology, 39, 543-550. Epub 12 May 2008. doi:10.1165/rcmb.2008-00280C

[40] McKinley, L., Alcorn, J.F., Peterson, A., Dupont, R.B., Kapadia, S., Logar, A., Henry, A., Irvin, C.G., Piganelli, J.D., Ray, A. and Kolls, J.K. (2008) TH17 cells mediate steroid-resistant airway inflammation and airway hyperresponsiveness in mice. The Journal of immunology: Official Journal of the American Association of Immunologists, 181, 4089-4097.

[41] Al-Ramli, W., Préfontaine, D., Chouiali, F., Martin, J.G., Olivenstein, R., Lemière, C. and Hamid, Q. (2009) T(H)17associated cytokines (IL-17A and IL-17F) in severe asthma. The Journal of Allergy and Clinical Immunology, 123, 1185-1187. Epub 10 April 2009. doi:10.1016/j.jaci.2009.02.024

[42] Vazquez-Tello, A., Semlali, A., Chakir, J., Martin, J.G., Leung, D.Y., Eidelman, D.H. and Hamid, Q. (2010) Induction of glucocorticoid receptor-beta expression in epithelial cells of asthmatic airways by T-helper type 17 cytokines. Clinical and Experimental Allergy: Journal of the British Society for Allergy and Clinical Immunology,
40, 1312-1322. Epub 9 June 2010. doi:10.1111/j.1365-2222.2010.03544.x

[43] Beck, I.M., Vanden Berghe, W., Vermeulen, L., Yamamoto, K.R., Haegeman, G. and De Bosscher, K. (2009) Crosstalk in inflammation: The interplay of glucocorticoid receptor-based mechanisms and kinases and phosphatases. Endocrine Reviews, 30, 830-882. Epub 4 November 2009. doi:10.1210/er.2009-0013

[44] Kobayashi, Y., Mercado, N., Barnes, P.J. and Ito, K. (2011) Defects of protein phosphatase 2A causes corticosteroid insensitivity in severe asthma. PloS One [Electronic Resource], 6, e27627. Epub19 December 2011. doi:10.1371/journal.pone.0027627

[45] Bouazza, B., Krytska, K., Debba-Pavard, M., Amrani, Y., Honkanen, R.E., Tran, J. and Tliba, O. (2012) Cytokines alter glucocorticoid receptor phosphorylation in airway cells: Role of phosphatases. American Journal of Respiratory Cell and Molecular Biology, 47, 464-473. Epub 16 May 2012. doi:10.1165/rcmb.2011-0364OC

[46] Hamid, Q.A., Wenzel, S.E., Hauk, P.J., Tsicopoulos, A., Wallaert, B., Lafitte, J.J., Chrousos, G.P., Szefler, S.J. and Leung, D.Y. (1999) Increased glucocorticoid receptor beta in airway cells of glucocorticoid-insensitive asthma. American Journal of Respiratory and Critical Care Medicine, 159, 1600-1604.

[47] Li, L.B., Leung, D.Y., Martin, R.J. and Goleva, E. (2010) Inhibition of histone deacetylase 2 expression by elevated glucocorticoid receptor beta in steroid-resistant asthma. American Journal of Respiratory and Critical Care Medicine, 182, 877-883. Epub 10 June 2010. doi:10.1164/rccm.201001-0015OC

[48] Butler, C.A., McQuaid, S., Taggart, C.C., Weldon, S., Carter, R., Skibinski, G., Warke, T.J., Choy, D.F., McGarvey, L.P., Bradding, P., Arron, J.R. and Heaney, L.G. (2012) Glucocorticoid receptor $\beta$ and histone deacetylase 1 and 2 expression in the airways of severe asthma. Thorax, 67, 392-398. Epub 8 December 2011. doi:10.1136/thoraxjnl-2011-200760

[49] Tliba, O., Damera, G., Banerjee, A., Gu, S., Baidouri, H., Keslacy, S. and Amrani, Y. (2008) Cytokines induce an early steroid resistance in airway smooth muscle cells: Novel role of interferon regulatory factor-1. American Journal of Respiratory Cell and Molecular Biology, 38, 463-472. Epub 18 October 2007. doi:10.1165/rcmb.2007-02260C

[50] Roos, A.B. and Nord, M. (2012) The emerging role of C/EBPs in glucocorticoid signaling: Lessons from the lung. The Journal of Endocrinology, 212, 291-305. Epub 1 November 2011. doi:10.1530/JOE-11-0369

[51] Roussel, L., Robins, S., Schachter, A., Bérubé, J., Hamid, Q. and Rousseau, S. (2011) Steroids and extracellular signal-regulated kinase $1 / 2$ activity suppress activating transcription factor 3 expression in patients with severe asthma. The Journal of Allergy and Clinical Immunology, 127, 1632-1634. Epub 22 April 2011. doi:10.1016/j.jaci.2011.03.034

[52] Adenuga, D., Caito, S., Yao, H., Sundar, I.K., Hwang, J.W., Chung, S. and Rahman, I. (2010) Nrf2 deficiency influences susceptibility to steroid resistance via HDAC2 
reduction. Biochemical and Biophysical Research Communications, 403, 452-456. Epub 19 November 2010. doi:10.1016/j.bbrc.2010.11.054

[53] Irusen, E., Matthews, J.G., Takahashi, A., Barnes, P.J., Chung, K.F. and Adcock, I.M. (2002) p38 Mitogen-activated protein kinase-induced glucocorticoid receptor phosphorylation reduces its activity: Role in steroid-insensitive asthma. The Journal of Allergy and Clinical Immunology, 109, 649-657. doi:10.1067/mai.2002.122465

[54] Goleva, E., Li, L.B. and Leung, D.Y. (2009) IFN-gamma reverses IL-2- and IL-4-mediated T-cell steroid resistance. American Journal of Respiratory Cell and Molecular Biology, 40, 223-230. Epub 5 September 2008. doi:10.1165/rcmb.2007-03270C

[55] Bhavsar, P., Khorasani, N., Hew, M., Johnson, M. and Chung, K.F. (2010) Effect of p38 MAPK inhibition on corticosteroid suppression of cytokine release in severe asthma. The European Respiratory Journal: Official Journal of the European Society for Clinical Respiratory Physiology, 35, 750-756. Epub 19 October 2009. doi:10.1183/09031936.00071309

[56] Ito, K., Caramori, G. and Adcock, I.M. (2007) Therapeutic potential of phosphatidylinositol 3-kinase inhibitors in inflammatory respiratory disease. The Journal of Pharmacology and Experimental Therapeutics, 321, 1-8. Epub 4 October 2006. doi:10.1124/jpet.106.111674

[57] Xystrakis, E., Kusumakar, S., Boswell, S., Peek, E., Urry,
Z., Richards, D.F., Adikibi, T., Pridgeon, C., Dallman, M., Loke, T.K., Robinson, D.S., Barrat, F.J., O'Garra, A., Lavender, P. Lee, T.H., Corrigan, C. and Hawrylowicz, C.M. (2006) Reversing the defective induction of IL-10secreting regulatory $\mathrm{T}$ cells in glucocorticoid-resistant asthma patients. The Journal of Clinical Investigation, 116, 146-155. Epub 8 December 2005.

[58] Ito, K., Lim, S., Caramori, G., Chung, K.F., Barnes, P.J. and Adcock, I.M. (2001) Cigarette smoking reduces histone deacetylase 2 expression, enhances cytokine expression, and inhibits glucocorticoid actions in alveolar macrophages. FASEB Journal: Official Publication of the Federation of American Societies for Experimental Biology, 15, 1110-1112.

[59] Didon, L., Barton, J.L., Roos, A.B., Gaschler, G.J., Bauer, C.M., Berg, T., Stämpfli, M.R. and Nord, M. (2011) Lung epithelial CCAAT/enhancer-binding protein- $\beta$ is necessary for the integrity of inflammatory responses to cigarette smoke. American Journal of Respiratory and Critical Care Medicine, 184, 233-242. Epub 11 May 2011. doi:10.1164/rccm.201007-1113OC

[60] Sutherland, E.R., Lehman, E.B., Teodorescu, M. and Wechsler, M.E.; National Heart, Lung, and Blood Institute's Asthma Clinical Research Network (2009) Body mass index and phenotype in subjects with mild-to-moderate persistent asthma. The Journal of Allergy and Clinical Immunology, 123, 1328-1334, e1. doi:10.1016/j.jaci.2009.04.005 